Negotiations and Reciprocities:

Social Relations Among Local

Potentates and their Armed Slaves

in Minas Gerais in the First Half of the $18^{\text {th }}$ Century

\title{
Negociações e reciprocidades: interações entre potentados locais e seus escravos armados nas Minas Gerais na primeira metade do século XVIII
}

\section{Ana Paula Pereira Costa}

Doutoranda em História pela

Universidade Federal do Rio de Janeiro

\section{Resumo}

0 texto objetiva investigar a prática dos potentados locais da comarca de Vila Rica de utilizar escravos armados em variadas situações em que prestavam serviços ao Monarca português em busca de mercês régias. Neste sentido analisaremos como, através do emprego de negociações e reciprocidades entre potentados e seus escravos, os primeiros conseguiam aquisição e manutenção de seu poder de mando; e, ao mesmo tempo, que tipos de benefícios e ganhos os escravos podiam adquirir com estas interações.

\section{Abstract}

The text aims to research the habit of local potentates, from the district of Vila Rica, of using armed slaves when they rendered services to the Portuguese Monarch in order to gains royal favors. Hence, we will analyze how, by means of negotiations and reciprocities between potentates and their slaves, the first ones acquired and maintained their power; and, at the same time, what types of benefits and gains the slaves could aspire to obtain with these relations.

Palavras-chave

elites, escravos, Minas Gerais

Keyword

elites, slaves, Minas Gerais 
BOXER, Charles. Vila Rica de Ouro Preto. In: A Idade do Ouro do Brasil. Rio de Janeiro: Nova Fronteira, 2000.

MONTEIRO, Rodrigo Bentes. O rei no espelho. A Monarquia portuguesa e a colonização da América, 1640-1720. São Paulo: Ed. Hucitec, 2002. p.285-286.

3

BICALHO, Maria Fernanda. Sertão de estrelas: a delimitação das latitudes e das fronteiras na América portuguesa. Varia Historia. Revista do Departamento de História da UFMG, Belo Horizonte, no. 21, p.81, julho de 1999.

4

CAMPOS, Maria Verônica. Goiás da década de 1730: pioneiros, elites locais, motins e fronteiras. In: BICALHO, Maria Fernanda. \&t FERLINI, Vera Lúcia do Amaral (Orgs.). Modos de Governar. Idéias e práticas políticas no Império português, séculos XVI a XIX. São Paulo: Alameda, 2005. p.342.

5

Ver: FERNANDES, Florestan. A sociedade escravista no Brasil. In: . Circuito fechado. São Paulo: Hucitec, 1976. NOVAIS, Fernando. Portugal e Brasil na crise do antigo sistema colonial. São Paulo: Hucitec, 1979. SOUZA, Laura de Mello e. 0 sol e a sombra: politica e administração na América portuguesa do século XVIII. São Paulo: Cia. das letras, 2006. p.56.
No século XVIII a região das Minas Gerais tornou-se importantíssima para o Império português, visto que o ouro desta capitania passou a ter papel significativo no cenário mundial deste período, equilibrando as finanças lusitanas ${ }^{1}$. A existência de ouro na região foi comunicada à Coroa na década de 1690. Confirmadas as notícias da descoberta das lavras, várias "bandeiras" paulistas, gente do nordeste, do Espírito Santo e reinóis se dirigiram para as Minas. De fato foram para a capitania inúmeras pessoas com objetivos e desempenho de atividades diferentes. Do sertão de São Francisco - o rio dos Currais - vinham negociantes de gado para tentar suprir o ainda incipiente abastecimento alimentar local, quando o afluxo de gente superava suas condições de sustento. Vinham também da Bahia comerciantes de escravos, dada a crise da lavoura açucareira e a demanda de mão-de-obra gerada pela nova atividade nas minas. Vinham os paulistas embasados em sua economia de apresamento indígena, mas em busca também do ouro. Mas vinham notadamente novos mineradores em potencial, de várias regiões e de Portugal, para concorrer com os paulistas pela posse das minas e participação na administração local2.

Portanto, Minas Gerais era nesses anos iniciais uma região de fronteira, o que não se refere a um limite preciso, a uma linha demarcatória, a uma raia ou divisão. Ao contrário, ir em fronteira, era o mesmo que ir em uma expedição, geralmente expedições armadas, com objetivos exploratórios, de conquista ${ }^{3}$. Nesse sentido era uma região que abria novas oportunidades econômicas e de mando para indivíduos de diferentes procedências sociais e econômicas, com a promessa de remuneração e mercês para os que contribuissem para o crescimento do Império luso ${ }^{4}$.

A 'conquista' desse sertão mineiro foi feita às custas das vidas, fazendas e escravos armados dos individuos que se arriscavam em tais empreitadas, sendo este o diferencial no sucesso ou fracasso das mesmas. Em outras palavras, na colonização da América portuguesa, a Coroa recorreu em vários momentos às "fazendas e negros armados" de seus súditos, pois, no ultramar, diante da dificuldade da metrópole em financiar as despesas com entradas, expansões territoriais e defesa da colônia, não raro se transferiram tais custos aos colonos que se tornavam assim os maiores responsáveis pela reprodução desta sociedade.

Mais do que a participação dos colonos na 'conquista' do território colonial o que afirmações como estas deixam explícito é a importância dos escravos para seus senhores. A importância destas ligações com os escravos se evidencia não só porque na sociedade colonial o escravismo articulava as relações sociais ${ }^{5}$, mas porque em muitos casos esses cativos forneceram segurança aos primeiros descobridores, povoadores e conquistadores da região; transformados depois em poderosos locais, atuando como uma pequena milicia privada para proteger e conferir autoridade a tais pioneiros nas diligências que faziam em nome Del Rey na primeira metade do século XVIII.

De fato, desde o alvorecer da colonização das Minas era comum que os poderosos locais agregassem em torno de si um séqüito de escravos armados para deles se utilizarem em suas diligências, sejam estas em prol da Coroa, seja em desmandos e contendas pessoais. Muitos contemporâneos destes anos iniciais da formação da sociedade mineira deixaram relatos que retrataram esse cenário, muitas vezes de forma pejorativa. Na "Relação do princípio do descoberto destas Minas Gerais e os sucessos de algumas coisas mais memoráveis que sucederam do seu principio até o tempo em que as veio governar o Excelentíssimo Senhor dom Brás da Silveira", o fenô- 
6

FIGUEIREDO, Luciano Raposo e CAMPOS, Maria Verônica (coord.). Códice Costa Matoso. Belo Horizonte: Fundação João Pinheiro, vol. I e II, 1999. p.194-202.

Ibidem, p.197.

Ibidem.

Ver: TAUNAY, Afonso de. Relatos sertanistas. São Paulo: Ed. Itatiaia, 1981. p.67-70.

\section{0}

LIMA Jr. Augusto de. Vila Rica do Ouro Preto. Sintese histórica e descritiva. Belo Horizonte: Edição do autor, 1957. p.73.

11

FRAGOSO, João. Alternativas metodológicas para a história econômica e social: micro-história italiana, Fredrik Barth e a história econômica colonial. In: ALMEIDA, Carla Maria Carvalho de e OLIVEIRA, Mônica Ribeiro de. (Orgs.). Nomes e números: alternativas metodológicas para a história econômica e social. Juiz de Fora: Ed. da UFJF, 2006. p.5.

\section{2}

PUJOL, Xavier Gil. Centralismo e localismo? Sobre as relações políticas e culturais entre capital e territórios nas monarquias européias dos séculos XVI e XVII. Penélope. Fazer e Desfazer a História, Lisboa, nº. 6, p.136, 1991. meno de armar escravos é descrito como algo que proporcionava respeito e vantagem para certos grupos, mas que também indicava audácia e violências ${ }^{6}$. Segundo o autor da Relação: "naquele tempo quem tinha de 20 a 30 escravos era respeitado pelos seus companheiros, sobretudo os paulistas que gostavam de exibir suas armas como fastos indicantes de suas dissimuladas proezas"7. Tanto que um renomado potentado paulista que habitava a capitania neste período, Jerônimo Pedroso de Barros, tinha a alcunha de 'Jerônimo Poderoso' "por ter este também bastante escravos, saindo sempre com sua gente que se the tinha agregado a ele, todos armados"8.

Com efeito, sempre que a documentação de época, bem como os relatos contemporâneos, vão se referir à figura do poderoso, mencionam que estes possuiam grande armamento e enorme contingente de escravos e/ou agregados. Estes foram os casos de figuras célebres das primeiras décadas de formação da capitania tais como Manuel Nunes Viana, Domingos da Silva Monteiro, Jerônimo Pedroso de Barros, Bartolomeu Bueno Feio, Salvador Fernandes Furtado de Mendonça, Pascoal da Silva Guimarães, dentre muitos outros 9 .

0 governador Martinho de Mendonça Pina e Proença, que em 1730 foi para Minas organizar as arrecadações dos quintos e dos diamantes, em relatório que escreve ao Rei D. João $V_{1}$ resumia assim os anos iniciais da região em relação aos potentados:

Era naquele tempo o país habitado por paulistas acostumados à insolência e soltura, e de portugueses de baixíssima extração, sem cultura; nem uns nem outros tinham de seu mais que armas, negros e ouro que the davam atrevimento e ocasião para as revoltas, receiando pouco o castigo porque era fácil se retirarem ao mato ${ }^{10}$.

Apesar de nos relatos citados a posse de escravos armados ser apontada como algo pejorativo, visto que abria procedência para se agir com desmando e violência tornando esses indivíduos figuras temidas, não há como negar que o acesso o grande número de cativos fazia parte da caracterização de alguém como poderoso.

Como já mencionado, os escravos armados foram usados em muitas diligências para prestação de serviços à Coroa, tanto os referentes à 'conquista' da terra (ajudando, por exemplo, no combate a levantes internos e externos), quanto em serviços mais "burocráticos", como cobranças de quintos reais e transporte dos mesmos. Desta forma, a posse de numerosa escravaria foi fundamental na definição de um indivíduo como poderoso não só porque a quantidade de escravos, juntamente com a posse de terras, ajudava na definição do lugar social, mas também porque a posse destes mesmos escravos foi vital para dinamizar e por em prática um mecanismo essencial de afirmação destes poderosos: a prestação de serviços à Coroa. Para além disso, possuir muitos escravos e utilizá-los como braço armado em prestação de serviços à Coroa foi fundamental também porque indicava a legitimidade e o poder de mando destes indivíduos.

Assim sendo, cabe sublinhar que o poder das elites no território colonial não era automático: ele pressupunha legitimidade social. Esta era construída entre tensões, conflitos e negociações através de entendimentos com ministros do Rei, lavradores, libertos, comerciantes e, principalmente, por meio de refinadas barganhas com os escravos ${ }^{11}$. Entretanto, pouco se sabe acerca das complexas redes de relações que tais elites locais estabeleciam com a sociedade mais ampla para conseguirem exercer seu mando, ou seja, como conseguiam legitimidade dos demais segmentos sociais ${ }^{12}$. 
Negociação aqui é entendida como um mecanismo que nega uma autoridade pura e simplesmente imposta, visto que nos possibilita compreender a interação como um processo de barganha de interesses específicos. 0 que estamos afirmando é que não há uma rejeição total das pressões e intenções dominantes, e sim tentativas de modificação dos tramites das formas de interação por parte dos "subalternos" a luz de suas necessidades e interesses. Neste sentido a idéia de negociação indica que os atores ao se relacionarem e lançarem mão de certos comportamentos, a primeira vista contrários à suas posições sociais, não podem tomar livremente certas deliberações por prescindirem um do outro no jogo das relações sociais.

\section{4}

Esta é compreendida como um sistema de trocas por meio do qual se mantêm laços de solidariedade social, ou seja, através de um sistema de negação/doação pessoal gera-se um ganho também pessoal.

15

DAVIS, David B. Introduction. In: BROWN, Christopher Leslie and MORGAN, Philip D. (Orgs.). Arming slaves: from classical times to the modern age. New Have \& London, Yale University Press, 2006. p.1.

\section{6}

Ibidem, p.2.

17

Neste sentido ver a coletânea de artigos do livro de BROWN, Christopher Leslie and MORGAN, Philip D. (Orgs.). Arming slaves: from classical times to the modern age. New Have \&t London, Yale University Press, 2006.

18

Ver: HUNT, Peter. Arming slaves and Helots in Classical Greece. In: BROWN, Christopher Leslie and MORGAN, Philip D. (Orgs.). Op.Cit., p.14-39.
Pretendemos com o presente texto lançar algumas reflexões acerca da existência e importância das negociações ${ }^{13}$ e reciprocidades ${ }^{14}$ entre um segmento das elites, isto é, os poderosos da localidade, em um importante território da América portuguesa, no caso a Comarca de Vila Rica em Minas Gerais, com os escravos. Investigaremos assim a prática de se utilizar escravos armados em variadas situações e o que possibilitava aos senhores armarem tais cativos sem temores de retaliações. Neste sentido, analisaremos como tais negociações e reciprocidades tecidas entre tais senhores/potentados e seus escravos auxiliaram, por um lado, na aquisição e manutenção do poder desses homens; e de outro, que tipos de benefícios e ganhos os escravos adquiriram com estas interações.

A mobilização dos escravos armados na prestação de serviços a Del Rey A idéia de senhores armarem seus escravos e com eles montarem uma "milícia privada" pode a princípio parecer-nos muito contraditória. Tradicionalmente a imagem que se construiu acerca dos escravos foi a do "inimigo doméstico", ou a da mercadoria preciosa sob a qual o senhor poderia exercer total domínio, ou a de seres traiçoeiros sempre prontos a se rebelarem contra seus donos. Sendo assim, porque seus senhores supririam esses "inimigos" com armas? Como bem lembrou David Brion Davis, podemos fazer uma analogia deste argumento com uma realidade atual ao pensarmos que armar escravos seria algo similar a fornecer armas e granadas aos condenados das penitenciárias de segurança máxima ${ }^{15}$.

Levando em consideração os vários relatos empíricos que mostram a presença de escravos armados lutando ao lado e, às vezes, defendendo seus senhores, uma importante questão a ser considerada é: porque alguns escravos escolheriam lutar pelos seus donos? A compreensão dessa questão de como e porque agiam esses escravos armados é fundamental para apreendermos o funcionamento da instituição humana mais degradante de toda a história16.

Recentemente alguns estudiosos procuraram entender a questão de armar os escravos a partir a idéia de "doutrina da necessidade", isto é, a precedência da auto-preservação sobre outros princípios. Nestes estudos os autores argumentam que em momentos críticos de estado de guerra a autopreservação podia demandar a utilização arriscada de escravos armados. Assim, em diferentes contextos, a doutrina da necessidade desempenhou um papel de fundamental importância na sobrevivência dos indivíduos ${ }^{17}$.

Peter Hunt, por exemplo, em recente trabalho no qual analisa o uso de escravos armados na Grécia e na Roma clássica, destaca que apesar dos antigos gregos e romanos frequentemente expressarem uma aversão ideológica do alistamento de escravos em seus exércitos que supostamente eram compostos por soldados cidadãos - no caso dos atenienses, fazendeiros independentes que eram conhecidos por sua coragem e confiança - em situações emergenciais tanto os gregos quanto os romanos não hesitavam em utilizar escravos e libertos no serviço militar. Seja utilizando-os como remadores na marinha ateniense, como carregadores de escudos e armaduras para seus senhores ou como tropa de combate, eles se tornaram uma força poderosa e indispensável especialmente em longas e desesperadas guerras ${ }^{18}$.

Outro exemplo encontramos no trabalho de Allen Isaacman e Derek Peterson. Os autores pesquisaram um grupo de escravos militarizados encontrados no sul da África denominados "chikunda", entre os anos de 
19

Ver: ISAACMAN, Allen \&t PETERSON, Derek. Making the Chikunda: military slavery and ethnicity in southern Africa, 1750-1900. In: BROWN, Christopher Leslie and MORGAN, Philip D. (Orgs.). Arming slaves: from classical times to the modern age. New Have \& London, Yale University Press, 2006. p.95-119.

20

Ver estudo de AMITAI, Reuven. The Manluk institution, or one thousand years of military slavery in the Islamic world. In: BROWN, Christopher Leslie and MORGAN, Philip D. (Orgs.). Op.Cit., p.40-78.

21

DAVIS, David B. Introduction. In: BROWN, Christopher Leslie and MORGAN, Philip D. (Orgs.). Op.Cit., p.5.
1750 a 1900. Esta região era escravizada pelos portugueses e estes, bem como seus descendentes, se empenharam em criar uma tradicional classe de escravos africanos que viam a si mesmos como ferozes conquistadores. Tatuagens faciais, vestimentas especiais e linguagem corporal reforçavam a celebração dos chikundas como guerreiros sem rivais nos quesitos coragem, força física e arrogância. Separados de suas famílias e tribos desde o nascimento, eles eram criados por outros grupos como outsiders e foram utilizados não somente em combates e nas investidas para coletar escravos e mandá-los em navios negreiros para o Brasil, mas também como policiaisinspetores e como experientes caçadores de elefantes que poderiam ajudar na demanda do Novo Mundo por marfim. Mas a despeito de seu poder e bravura os chikundas ainda eram escravos que viviam e obedeciam ordens num mundo altamente regimentado ${ }^{19}$.

Esta realidade também se fez presente nas regiões da península arábica e da Turquia. Tanto nos exércitos árabes e turcos quanto em milícias particulares era generalizado o uso de escravos armados. Tais escravos eram conhecidos como "mamluk" e representavam um tipo altamente distinto de escravidão. Assim como os chikundas, eram trazidos ainda crianças de regiões distantes como o mar Cáspio e o mar Negro e eram treinados para serem protetores devotos. Contudo, apesar desses mamluks serem explorados como soldados que a todo momento arriscavam suas vidas, essa instituição peculiar de escravidão mostrava pouca intenção em desumanizar os jovens guerreiros que eram altamente disciplinados em arte de guerra, principalmente no uso do arco e flecha e da montaria. Portanto, como eram desprovidos de qualquer identidade familiar ou tribal esperava-se que eles se unissem uns aos outros e especialmente a um patrão ou sultão a quem eles deveriam expressar lealdade incondicional ${ }^{20}$.

Os estudos citados sugerem que usar escravos armados - seja em "exércitos formais" seja em milícias particulares -, não era algo nada excepcional, sendo esta uma prática comum a diferentes épocas e lugares; prática esta que também foi levada para as Américas portuguesa e espanhola. 0 contato dos portugueses e espanhóis com esses fenômenos pode ter se iniciado durante o período de ocupação moura na península ibérica. Ao contrário dos antigos gregos e romanos ou de muitos europeus que colonizaram o Novo Mundo, os muçulmanos parecem ter demonstrado pouco medo em armar alguns escravos pré-condicionados. Os escravos escravizados pelos muçulmanos, advindos da região do Cáucaso entre os mares Negro e Cáspio, eram alienados da sua origem, linguagem e educados por outros grupos étnicos. Essas tropas caucasianas tiveram um papel decisivo na derrota dos cristãos bizantinos; em conquistar e "criar" a Turquia; em repelir os cruzados europeus do Egito até a Terra Santa e em parar as invasões dos mongóis. Além disso, esses árabes muçulmanos e os berberes foram aqueles que iniciaram o comércio de longa distância dos escravos africanos da região sub-saariana. Durante um período de pelo menos onze séculos suas caravanas e navios transportaram milhões de escravos negros para o Norte da África, Sicília e Espanha21.

Dada a longa ocupação moura em Portugal e na Espanha os cristãos ibéricos puderam se informar acerca da experiência muçulmana em armar escravos. Desta forma não é demais argumentar a importância e influência deste fato para os primeiros exploradores espanhóis e portugueses que conquistaram o Novo Mundo. Como demonstrado por Jane Landers e 
Ver: KRAAY, Hendrik. Arming slaves in Brazil from the seventeenth century to the nineteenth century, p. 146-179; LANDERS, Jane. Transforming bondsmen into vassals: arming slaves in colonial Spanish America, p. 120-145. e DAVIS, David B. Introduction. In: BROWN, Christopher Leslie and MORGAN, Philip D. (Orgs.). Arming slaves: from classical times to the modern age. New Have \& London, Yale University Press, 2006

23

LANDERS, Jane. Op.Cit., p.120-145.

24

DAVIS, David B. Op.Cit., p.7.

25

LIMA, Carlos A. M. Escravos de Peleja: a instrumentalização da violência escrava na América portuguesa (1580-1850). Revista de Sociologia e Política, no. 18, p.149, jun. 2002.

26

KRAAY, Hendrik. Op.Cit., p.146-179.

27

PAIVA, Eduardo França. De corpo fechado: o gênero masculino, milícias e trânsito de culturas entre a África dos mandingas e as Minas Gerais da América, no início do século XVIII. In: LIBBY, Douglas Cole \& FURTADO, Júnia F. (Orgs.) Trabalho livre, trabalho escravo: Brasil e Europa, séculos XVIII e XIX. São Paulo: Annablume, 2006. p.118.
Hendrik Kraay os escravos armados dos ibéricos e os negros livres e mulatos foram utilizados desde muito cedo na 'conquista' ultramarina 22.

Jane Landers apontou a tradição da lei romana e das Siete Partidas do século XIII que se, por um lado, legitimaram a escravidão, por outro, também encorajaram o uso da manumissão como recompensa para aqueles escravos que prestassem serviços para o Estado. Desta forma muitos escravos negros adentraram o serviço militar como uma rota para a liberdade e assimilação, e a despeito de protestos de plantadores brancos e soldados, um enorme número de libertos e escravos milicianos defenderam os interesse da Espanha, de Cuba até o Peru23.

Já em relação aos portugueses, cuja colônia no Brasil absorveu mais escravos da África que todas as colônias espanholas juntas, a situação é um pouco mais ambígua. Para Brion Davis os portugueses foram muito mais relutantes em usar escravos e/ou libertos armados em seus "exércitos" ou como "guarda-costas" pessoais:

Como uma verdadeira sociedade escravista cuja produção maciça de açúcar e de café dependia inteiramente do trabalho escravo e da contínua importação destes da África, os oficiais brasileiros ficaram receosos em permitir que os escravos carregassem ou adquirissem armas especialmente em periodos posteriores a insurreições ${ }^{24}$. (tradução livre)

Todavia, alguns autores demonstraram que era relativamente comum que senhores armassem seus escravos no Brasil colonial, desde o século XVI até o século XIX, em diferentes paragens. A respeito disso Carlos Lima destacou como que no periodo colonial a Coroa lusa tirou partido da capacidade dos senhores de mobilizar a "guerra escrava". Na verdade, segundo este autor, havia uma aliança entre Coroa e senhores para que a primeira recorresse à mobilização de escravos para a defesa do território colonial, ancorada na capacidade senhorial de instrumentalizar os seus cativos. Neste sentido, assinala como foi coisa eminentemente normal o escravo andar sozinho e armado, até porque muitos eram usualmente envolvidos nos conflitos pessoais de seus senhores, o que para o autor foi uma característica ou paradigma da governação ilustrada na América Portuguesa25.

Já Hendrik Kraay, outro estudioso do tema, observou que o fato dos senhores armarem seus próprios escravos se tornou rotina nas fronteiras sem lei e durante o período do boom da mineração em Minas Gerais.

Segundo este autor, para os escravos, o serviço militar, "formal" ou pessoal, ofereceu uma bem vinda válvula de escape contra a miséria e a degradação do trabalho nas plantations ou nas lavras, para o caso da capitania mineira. A esperança de uma promessa de liberdade juntamente com uma mudança de status dai advinda poderia trazer a possibilidade de mobilidade, dignidade e prestígio 26 .

Eduardo França Paiva também destacou que escravos armados, apesar de ter sido algo que as autoridades coloniais temiam fortemente e proibiam, sempre foi uma situação comum na América Portuguesa. Para o caso de Minas Gerais assinala que durante as primeiras décadas de ocupação das terras mineradoras isso se repetiu com freqüência, não deixando de fomentar violências e desmandos da parte dos proprietários que haviam montado suas milícias escravas e por parte dos próprios escravos armados. Segundo o autor, até mesmo a Coroa acabou incorporando tal prática, montando tropas de escravos armados e, também, os convocando entre os proprietários leais ao governo ${ }^{27}$. 
28

Arquivo da Câmara de Mariana. Lista de registro para cobrança dos quintos reais de 1725. Códice 150.

\section{9}

Arquivo Histórico Ultramarino, Minas Gerais, cx.86; doc.17.

30

Ibidem. Grifo meu.

31

FRANCO, Francisco de Assis Carvalho. Dicionário de Bandeirantes e Sertanistas do Brasil. Belo Horizonte: Itatiaia; São Paulo: Ed. USP, 1989. p.295.

32

Arquivo Histórico Ultramarino, Minas Gerais, cx.22; doc. 64 .

33

Ibidem.

34

Ibidem.

35

Ibidem. Grifo meu.
Para ilustrar tudo o que acabamos de mencionar destaco o caso do coronel Caetano Álvares Rodrigues, um dos homens mais poderosos das Minas Gerais em suas primeiras décadas. No registro produzido em 1725 para a cobrança dos quintos reais (imposto de 20\% sobre a produção aurífera), este potentado foi descrito como um grande proprietário de cativos: possuía 80 escravos na freguesia de São Sebastião ${ }^{28}$. Com tão grande plantel podia se dispor a redirecionar alguns de seus cativos das atividades da mineração para levá-los em suas diligências em que atuou como "cúmplice" da Coroa na manutenção da ordem pública. Assim o fez em 1711 quando ajudou "na expulsão dos franceses quando invadiram o Rio de Janeiro, sendo dos primeiros que se offereceo para acompanhar o governador com negros armados e o fez com despesa de sua fazenda"29. Ajudou ainda o governador de Minas e São Paulo, Conde de Assumar, em 1720 "a combater os revoltosos de Vila Rica acompanhando o dito governador com seus escravos armados até Vila Rica para castigar se os cabeças do levante"30.

Como um dos primeiros povoadores das Minas, Caetano Álvares Rodrigues atuou sistematicamente na 'conquista' da terra e em combate a levantes e conflitos internos da capitania a fim de angariar mercês e reconhecimento social. Se em tais confrontos foi acompanhado de seus escravos armados, podemos argumentar que sua postura nos informa sobre possiveis práticas de negociações.

Outro exemplo é o do mestre de campo José Rebelo Perdigão. Este reinol, natural de Lisboa, veio para o Brasil em 1697 acompanhando o governador Artur de Sá e Menezes instituído no cargo de secretário da repartição do sul. ${ }^{31}$ Ficou no Rio de Janeiro até aproximadamente 1700 atuando e acompanhando o dito governador em muitas diligências na capitania fluminense, no sul e em São Paulo, "sempre a fazer negócios de grande consideração com grave perigo de sua vida e despesa de sua fazenda"32. Em São Paulo:

Foi encarregado de averiguar crime de cunhos falços e pella sua fidellidade foi encarregado de tirar depoimento aos denunciados pellas justiças daquellas terras serem parentes e amigos dos delinqüentes (...) tirou assim testemunhos naquelle crime de que resultou prender se hum dos culpados sem levar sallarios ou fazer despesa da fazenda real ${ }^{33}$.

Foi ainda encarregado na vila de Taubaté de arrecadar os quintos:

E se ofereceu para levar ao Rio de Janeiro o ouro que arrecadou na vila o que fez sem despesa da fazenda real gastando nesta jornada 10 meses fazendo consideravel despesa não só com seus escravos armados mas também com os indios que conduzião o ouro ${ }^{34}$.

Acompanhou depois o governador Artur de Sá às Minas Gerais, onde atuou em algumas diligências com o mesmo governador "sempre com maior risco de vida e despesa de sua fazenda". No ano de 1701:

Tendo-se noticia de que nos campos do rio das velhas se descobriu um ribeiro de importância foi encarregado de ir ter com o seu descobridor e escolher a data de V. Mag, o que correu no maior perigo por todos quererem a milhor data, do que se originarão tumultos e mortes. Assim, por se querer partir os ribeiros a vontade dos poderosos régulos foi a todo risco a esta diligencia com amigos e escravos seos armados que o acompanharão fazendo a escolha com acerto por que foy a data de maior importancia dada a fazenda real ${ }^{35}$. 
36

Arquivo Histórico Ultramarino, Minas Gerais, cx.22; doc.64. Grifo meu.

37

Arquivo da Câmara de Mariana. Lista de registro para cobrança dos quintos reais de 1723. Códice 166.

38

Arquivo Histórico Ultramarino, Minas Gerais, cx.16; doc.3. Grifo meu.

39

Ibidem.Grifo meu.
40

LIMA, Carlos C. Pequenos Patriarcas. 1997. Tese (Doutorado). Rio de Janeiro: Universidade Federal do Rio de Janeiro, 1997. p.316-317. Apud: FERREIRA, Roberto Guedes. Autonomia escrava e (des) governo senhorial na cidade do Rio de Janeiro da primeira metade do sécuIo XIX. In: FLORENTINO, Manolo (Org.). Tráfico, cativeiro e liberdade. Rio de Janeiro, séculos XVII-XIX. Rio de Janeiro: Civilização Brasileira, 2005. p.249.
Ofereceu-se mais uma vez para conduzir ao Rio de Janeiro o ouro retirado desta data no Rio das Velhas "com despeza de sua fazenda as custas de seus escravos ${ }^{36}$.

Por fim destaco o caso do capitão-mor Manuel Jorge Coelho, também dos primeiros descobridores e povoadores das Minas Gerais e um grande proprietário de cativos. Em outro registro feito para cobrança dos quintos reais datado de 1723 para a freguesia de Catas Altas constava que possuía 76 escravos ${ }^{37}$. Encontramos relato de pelo menos duas diligências em que levou seus escravos como braço armado. No ano de 1720:

[...] Tendo-se notícias que no mato do Carassa havia um quilombo de negros fugidos donde fazião muitos roubos e mortes aos passageiros the ordenou o governador Conde de Assumar que fosse com os moradores do seo districto a castigar os ditos negros o que executou com muito acerto, sustentando a gente que levou em sua companhia e o seus escravos armados a suas custas todo o tempo que durou a dita diligência [...] ${ }^{38}$.

No mesmo ano, foi novamente chamado pelo Conde de Assumar a uma junta que este realizou para acabar com as desordens ocorridas em decorrência das novas arrecadações do quinto que naquele ano estavam sendo postas em prática, motim que ficou conhecido como revolta de Vila Rica. Nesta ocasião:

[...] Foi acudir ao governador e castigar a enormidade de tão grave dellito e o dito acompanhou o governador com bastante homens brancos armados e os seus escravos sustentado tudo a sua custa em todo o tempo que durou a diligencia no que fez uma considerável despesa [...] ${ }^{39}$.

Relatos como estes denotam indiretamente que a violência e o castigo não eram os únicos meios de se conseguir "subordinação" de um escravo. Consideramos que a imposição da autoridade do senhor não era dada exclusivamente pela força, mas também através de negociações e concessões que ajudavam no reconhecimento de sua legitimidade. 0 suposto aqui defendido é que seria muito contraditório armar um escravo e confiar que ele não se voltaria contra o senhor se fosse tratado apenas com violência e coerção. As relações entre senhor e escravo, ainda que tenham por fundamento uma absurda diferença de poder, a violência e a opressão de um ser humano sobre outro, têm de estar pautada em uma ligação de confiança em casos como os que venho analisando neste trabalho; confiança esta adquirida por meio de reciprocidades e negociações.

Desta maneira, os exemplos mostram que muito das relações entre senhores e escravos eram feitas de uma ética baseada em laços pessoais. Do ponto de vista do escravo, o senhor era aquele que Ihe informava sê-lo. Em outros termos, era de suma importância no relacionamento senhorescravo a figura do senhor enquanto indivíduo posicionado para a interação, e não apenas a sua condição senhoria| ${ }^{40}$. Ou seja, o fundamental nessa relação era a postura pessoal do senhor com seus cativos, ou dos seus intermediários com os mesmos. 0 respeito e a legitimidade perante seus escravos eram então construídos, e também exigidos, sobretudo na interação entre ambos. Não era algo dado, mas conquistado. Se assim não o fosse seria muito difícil explicar a possibilidade dos escravos de Caetano Álvares Rodrigues, José Rebelo Perdigão e Manuel Jorge Coelho portarem armas. A postura desses potentados indica que os mesmos não temiam que 
41

FRAGOSO, João. A nobreza vive em bandos: A economia política das melhores familias de terra do Rio de Janeiro, século XVII. Algumas notas de pesquisa. Tempo - Revista do Departamento de História da Universidade Federal Fluminense, Niterói, V.8, N.15, 2003, p. 20.

\section{2}

MALHEIRO, A. Perdigão. A Escravidão no Brasil: Ensaio Histórico, Jurídico, Social. (18661867). Petrópolis: Ed. Vozes, 1976, 2 v. Apud: PINHEIRO, Cláudio C. No Governo dos Mundos: escravidão contextos coloniais e administração de populações. Estudos Afro-Asiáticos, ano 24, no.3, p.435, 2002.

\section{3}

FRAGOSO, João. A formação da economia colonial no Rio de Janeiro e de sua primeira elite senhorial (séculos XVI e XVII). In: FRAGOSO, João; BICALHO, Maria Fernanda \& GOUVÊA, Maria de Fátima (Orgs.). 0 Antigo Regime nos trópicos: a dinâmica imperial portuguesa (séculos XVI - XVIII). Rio de Janeiro: Civilização Brasileira, 2001. p.58.

\section{4}

LIMA, Carlos A. M. Escravos de Peleja: a instrumentalização da violência escrava na América portuguesa (1580-1850). Revista de Sociologia e Politica, no. 18, p.139, jun. 2002

\section{5}

BICALHO, Maria Fernanda. Pacto colonial, autoridades negociadas e o Império Ultramarino Português. In: SOIHET, Raquel; BICALHO, Maria Fernanda e GOUVÊA, Maria de Fátima (Orgs.). Culturas politicas: ensaios de história cultural, história política e ensino de história. Rio de Janeiro: Mauad, 2005. p.98.

\section{6}

ENGEMANN, Carlos. Da comunidade escrava: Rio de Janeiro, séculos XVII-XIX. In: FLORENTINO, Manolo (Org.). Tráfico, cativeiro e liberdade. Rio de Janeiro, séculos XVII-XIX. Rio de Janeiro: Civilização Brasileira, 2005. p.189.

\section{7}

FERREIRA, Roberto Guedes. Autonomia escrava e (des)governo senhorial na cidade do Rio de Janeiro da primeira metade do século XIX. In: FLORENTINO, Manolo (Org.). Op.Cit., p.249.

48

ENGEMANN, Carlos. Op.Cit., p.189.

\section{9}

FLORENTINO, Manolo. Sobre minas, crioulos e a liberdade costumeira no Rio de Janeiro, 17891871. In: FLORENTINO, Manolo (Org.). Op.Cit., p.350.

50

FLORENTINO, Manolo. Alforrias e etnicidade no Rio de Janeiro oitocentista: notas de pesquisa. Topoi. Revista de história, Rio de Janeiro, $n^{\circ} .5$, p.26, 2002. alguns de seus cativos armados se revoltassem contra eles. Não podemos nos esquecer que estes confrontos poderiam se tornar momentos propicios para subversão dos escravos, principalmente se levarmos em conta que eles estavam armados. Assim, o fato de senhores armarem seus escravos deve ser visto como resultado de uma relação de interdependência bem sucedida entre ambos, sendo esse um bom índice para medir o "sucesso" das negociações e reciprocidades entre eles ${ }^{41}$.

Cláudio Pinheiro destacou que havia formas de convivio entre senhores e escravos que extrapolavam o simples uso da violência física como elemento responsável pela manutenção da escravidão, ou mesmo o uso da coerção para manter os cativos no trabalho. Citando Perdigão Malheiro, o referido autor assinala:

Pensar em melhorias das condições de vida dos escravos não era apenas uma questão de 'humanidade', mas de 'reciprocidade', já que um escravo bem tratado serviria de 'melhor vontade', tornar-se-ia 'melhor', e com isso lucraria não só o senhor, mas a sociedade, pois se conseguiria não apenas a 'paz nas famílias, e portanto na ordem pública', mas no resultado econômico em relação à produção 42 .

Mas em que se traduziriam as negociações e reciprocidades entre senhores e escravos no período enfocado? 0 que mediaria tais práticas entre os dois grupos em questão? Em outros termos, se estes "leais súditos" prestavam variados serviços ao Rei às custas de seus negros armados - e como visto isto foi essencial para o exercício do mando e manutenção da "qualidade" desses indivíduos, ou seja, na sua definição como poderoso - não é incorreto dizer que a "subordinação" destes escravos não podia ser feita apenas pela via da coerção, armas e castigos. Tal "subordinação" envolvia também negociações e reciprocidades 43 , ou, como bem destacou Carlos Lima, do ponto de vista do escravo, deve ter envolvido algo centrado na possibilidade de barganhar as condições do cativeiro 44 .

\section{Elementos negociados nas interações potentados/escravos armados}

A partir do que foi dito talvez possamos argumentar que entre seres humanos não há controles absolutos e coisificações de pessoas, e que nas relações de dominação, os dominantes não anulam os dominados, ainda que possa haver um grande desequilibrio de forças entre os dois lados ${ }^{45}$. Assim, a violência do senhor convivia com outros mecanismos compensatórios para aliviar a tensão que ela própria exercia sobre o cativeiro 46 . Neste sentido, pode-se dizer, como já mencionado, que o exercício da autoridade sobre o cativo era, muitas vezes, de natureza pessoal ${ }^{47}$. Destas relações pessoais emergiam, por um lado, as condições necessárias para a construção de referências que permitissem a caracterização de um senhor "legítimo" perante seus escravos, a ponto de armá-los sem temores de retaliações; e por outro, faziam surgir espaços sociais de ação dos escravos 48 que ordenavam as relações e tornavam o viver menos difícil e sofrido 49 . Dentre tais mecanismos, a família escrava foi destacada por muitos autores como elemento que indicava a capacidade dos escravos de construírem sólidos espaços de agregação social, de resistirem cotidianamente a alguns cânones da escravidão e, neste sentido, de expressar sua humanidade 50 . Não por acaso foi constantemente buscada pelos cativos e, por isso, será destacada neste trabalho como um dos mecanismos que poderiam ser utilizados nas negociações e reciprocidades dos potentados com seus escravos. 
Para o século XVIII ver: FARIA, Sheila de Castro. A colônia em movimento: fortuna e famí-

lia no cotidiano colonial. Rio de Janeiro: Nova Fronteira, 1998. Para o século XIX ver: GÒES, José Roberto. $O$ cativeiro imperfeito. Um estudo sobre a escravidão no Rio de Janeiro da primeira metade do século XIX. Vitória: Lineart, 1993. GÒES, José Roberto \& FLORENTINO, Manolo. A paz das senzalas; famílias escravas e tráfico atlântico, Rio de Janeiro c.1790 - c.1850. Rio de Janeiro: Civilização Brasileira, 1997. MOTTA, José Flávio. Corpos escravos, vontades livres: posse de cativos e familia escrava em Bananal (18011829). São Paulo: Annablume, 1999.

\section{2}

BOTELHO, Tarcisio. Família e escravidão em uma perspectiva demográfica: Minas Gerais (Brasil), século XVIII. In: LIBBY, Douglas Cole \&t FURTADO, Júnia F (Orgs.). Trabalho livre, trabaIho escravo: Brasil e Europa, séculos XVIII e XIX. São Paulo: Annablume, 2006. p.196.

53 GÒES, José Roberto \&t FLORENTINO, Manolo. Op.Cit.

\section{4}

GÒES, José Roberto \&t FLORENTINO, Manolo. Op.Cit., p.175.

\section{5}

FILHO, Afonso de Alencastro Graça, PINTO, Fábio Carlos Vieira \&t MALAQUIAS, Carlos de Oliveira. Familias escravas em Minas Gerais nos inventários e registros de casamento: o caso de São José do Rio das Mortes, 1743-1850. Varia Historia. Revista de História do Departamento da UFMG, Belo Horizonte, vol. 23, nº. 37, p.185186, Jan/Jun 2007.

\section{6}

ENGEMANN, Carlos. Da comunidade escrava: Rio de Janeiro, séculos XVII-XIX. In: FLORENTINO, Manolo (Org.). Tráfico, cativeiro e liberdade. Rio de Janeiro, séculos XVII-XIX. Rio de Janeiro: Civilização Brasileira, 2005. p.182.

\section{7}

FRAGOSO, João. Potentados coloniais e circuitos imperiais: notas sobre uma nobreza da terra, supracapitanias, no Setecentos. In: MONTEIRO, Nuno G., CARDIM, Pedro \&t CUNHA, Mafalda Soares da (Orgs.). Optima Pars - elites iberoamericanas do Antigo Regime. Lisboa, ISC Imprensa de Ciências Sociais, 2005. p.137.
Desde pelo menos a década de 1970 muitos autores chamaram atenção para a relativa incidência de vida familiar entre os cativos ${ }^{51}$. Desde trabalhos pioneiros que detectaram a presença de famílias cativas nos plantéis, passando por estudos que analisaram o comportamento dos cativos frente ao casamento, que ampliaram a definição de família, pensada em termos de convivio familiar e comunidade escrava, começou-se a pensar a família escrava como um elemento estrutural da escravidão brasileira e não como uma exceção. Para além disso, outros estudos buscaram avançar no entendimento da constituição de famílias por parte dos cativos, pensando tal elemento em uma perspectiva política ${ }^{52}$.

Nesse sentido temos o estudo de José Roberto Góes e Manolo Florentino. Analisando os plantéis no Rio de Janeiro entre os anos de 1790 a 1850, estes autores destacaram que a formação de familias podia trazer ganhos tanto para senhores quanto para os escravos ${ }^{53}$. Assim, para o senhor, a capacidade dos escravos de constituir família, tanto dentro quanto fora do casamento, servia a seus interesses na medida em que proporcionava certa sensação de estabilidade social e paz. Já para os cativos, a formação de familias constituia-se em estratégia para fazer aliados. Por meio do casamento e batismo eles estreitavam laços que nas dificeis condições da escravidão transformavam-se em laços de aliança e solidariedade 54 .

Para outros estudiosos a relevância da família escrava se relaciona às estratégias de forjar redes de solidariedade e resistência no cativeiro. A familia escrava seria um locus importante de tensões, na perspectiva do controle social por parte da casa-grande e na conquista de regalias pela senzala. Trata-se de uma relação entre desiguais, mas que impunha limites à ação senhorial de livre disponibilidade sobre seus escravos, passando a enfrentar a oposição dos laços de conjugais juridicamente construídos e da solidariedade comunitária. Disputas que minavam o domínio dos senhores escravistas 55 .

Carlos Engemann também destacou o grande peso que a família adquiriu no fortalecimento da comunidade escrava (entendida por ele como grandes plantéis que compartilhavam mito, rito e parentesco). Segundo o referido autor a produção de parentes pode ser considerada uma estratégia dos escravos para fortalecer o grupo na medida em que através da formação de familias se perpetuaram no tempo e produziram aliados ${ }^{56}$.

Os estudos citados alertam sobre a existência de acordos, negociações e reciprocidades na relação senhor/escravo, denotando que o sistema escravista se sustentava também sobre uma base de conciliação. Para além disso, eles nos informam sobre os possiveis conteúdos que poderiam ser negociados entre os poderosos da localidade e escravos na região e periodo enfocados. Em outros termos, estas barganhas, que possibilitavam ao senhor uma confiança tal em seu escravo a ponto de armá-lo, poderiam se traduzir na formação de famílias escravas estáveis nos plantéis, em terrenos e equipamentos cedidos pelos senhores, em alforrias, em redes parentais fictícias ${ }^{57}$, em melhoras nas circunstâncias de vida evidenciadas pelo aumento da expectativa de vida, do bem-estar material, em funções desempenhadas pelos escravos, moradia, melhores condições de trabalho e saúde, etc. Em estudo recente sobre o tema J. Fragoso destacou que estes fenômenos podem ser interpretados de diversos modos: conquista dos escravos retiradas de seus donos, estratagemas senhoriais para evitar problemas nas senzalas, recompensa senhorial pela subserviência de frações da população 


\section{8}

FRAGOSO, João. Potentados coloniais e circuitos imperiais: notas sobre uma nobreza da terra, supracapitanias, no Setecentos. In: MONTEIRO, Nuno G., CARDIM, Pedro \& CUNHA, Mafalda Soares da (Orgs.). Optima Pars - elites iberoamericanas do Antigo Regime. Lisboa, ISC Imprensa de Ciências Sociais, 2005. p.137.

\section{9}

Arquivo da Câmara de Mariana. Lista de registro para cobrança dos quintos reais de 1723. Códice 166.

\section{0}

Arquivo da Câmara de Mariana. Lista de registro para cobrança dos quintos reais de 1725 . Códice 150.

61

Casa Setecentista de Mariana, $2^{\circ}$ ofício - Inventário post-mortem de Manuel Jorge Coelho. Códice 15, auto 448, (1733).

62

Ibidem.

\section{3}

Arquivo da Câmara de Mariana. Lista de registro para cobrança dos quintos reais de 1723. Códice 166.

64

BOTELHO, Tarcísio. Família e escravidão em uma perspectiva demográfica: Minas Gerais (Brasil), século XVIII. In: LIBBY, Douglas Cole \& FURTAD0, Júnia F (Orgs.). Trabalho livre, trabaIho escravo: Brasil e Europa, séculos XVIII e XIX. São Paulo: Annablume, 2006. p.215.

65

Ver: Arquivo Histórico Ultramarino, Minas Gerais, cx.16, doc.3.

\section{6}

Segundo a legislação portuguesa e as listas de Ordenanças, que eram as encarregadas de fazer um arrolamento da população militarmente útil da colônia, eram considerados homens capazes de pegar em armas todos aqueles que tivessem idade entre 18 a 60 anos. Para o caso dos escravos cuja média de expectativa de vida freqüentemente não passava dos 40 anos estamos considerando esta faixa etária entre 18 a 40 anos. cativa, etc. Contudo, seja qual for a razão alegada, o fato era a presença destes fenômenos no cotidiano escravista 58 .

Vejamos então, através de alguns exemplos, como tais indícios se configuravam nas relações destes cativos com o grupo analisado. 0 já mencionado capitão-mor Manuel Jorge Coelho, que como visto anteriormente levou em duas diligências escravos como braço armado, era também um grande proprietário de cativos. Na lista de cobrança dos quintos reais na freguesia de Catas Altas do ano de 1723 relatou que era possuidor de 76 escravos ${ }^{59}$, em outra lista do ano de 1725 na mesma freguesia declarou que possuía 65 cativos $^{60}$ e no final de sua vida (faleceu no ano de 1733) possuía um plantel composto por 80 escravos $^{61}$.

Analisando o inventário de Manuel Jorge Coelho, observamos mais de perto as possibilidades de interações pautadas na negociação e reciprocidade dele com seus escravos que, muito provavelmente, permitiram sua utilização como braço armado sem preocupações, ao menos graves, de retaliações. Além disso, permitiram também sua caracterização como um senhor legítimo, isto é, como alguém cuja autoridade não se baseava unicamente no uso da força contra o escravo, mas como alguém que tinha sua autoridade e superioridade reconhecida através de mecanismos advindos do estabelecimento de relações pessoais com os mesmos. Em seu inventário, do total de seus 80 escravos, 60 eram homens e 20 eram mulheres. Entre os homens 46 eram africanos e entre as mulheres, 8. Assim, a proporção homem/mulher ficava na razão de 3 para 1. Das mulheres arroladas no plantel, 13 eram casadas, sendo todas as uniões sancionadas pela igreja. Neste plantel havia assim 13 arranjos familiares formais onde 39 cativos, ou seja, $48,75 \%$, se uniam por relações de parentesco 62 , porcentagem que podia ser ainda maior visto que, até o momento, não nos foi possivel mapear as relações de parentesco informais entre a escravaria.

Este retrato se difere bastante da constituição de seu plantel em 1723, período em que possuía 76 cativos, dos quais 57 eram homens africanos e 7 nascidos no Brasil. Entre as mulheres, que totalizavam 12, apenas uma era criola. Havia assim 5,33 homens para cada mulher ${ }^{63}$. Das mulheres mostradas na lista dos quintos reais cinco eram casadas e pelo menos três tinham relações informais, fato observado pelo batismo de seus filhos no periodo abordado ${ }^{64}$. Percebe-se assim que Manuel Jorge Coelho foi ampliando as possibilidades de seus cativos constituírem familias, o que provavelmente foi ajudado pela queda no desequilibrio sexual, que possibilitou maior estabilidade para a integração dos cativos. Tal constatação pode ser encarada como uma estratégia desse senhor, utilizando-se dos recursos que possuía no intuito de propiciar maiores "facilidades" para o estabelecimento de famílias em seu plantel, a fim de tirar a maior vantagem possivel nestas relações. Neste caso, ter a possibilidade de armar seus escravos e formar uma milícia particular para atuar com ele em suas diligências na busca de prestígio e distinção para exercer o seu mando.

Talvez possamos reforçar este argumento olhando mais de perto a formação destas famílias escravas relacionando o retrato encontrado no inventário em 1733 com o período de 1720, ano em que encontramos relatos da atuação de Manoel Jorge Coelho com milícias privadas de escravos ${ }^{65}$. Dos 60 homens de seu plantel, 32 estavam aptos (com idade entre 18 a 40 anos) para pegarem em armas e prestarem serviços em diligências com seu senhor no periodo de $1720^{66}$. Dentre estes escravos homens em idade propícia para 
67

Arquivo Eclesiástico da Arquidiocese de Mariana. Livro de Casamentos, F-26, p.26.

68

Casa Setecentista de Mariana, $2^{\circ}$ ofício - Inventário post-mortem de Manuel Jorge Coelho. Códice 15, auto 448, (1733).

\section{9}

Ver: Arquivo Histórico Ultramarino, Minas Gerais, cx.16, doc.3.

\section{0}

BOTELHO, Tarcísio. Família e escravidão em uma perspectiva demográfica: Minas Gerais (Brasil), século XVIII. In: LIBBY, Douglas Cole \&t FURTADO, Júnia F (Orgs.). Trabalho livre, trabaIho escravo: Brasil e Europa, séculos XVIII e XIX São Paulo: Annablume, 2006. p.215.

\section{1}

TAUNAY, Afonso de. Relatos sertanistas. São Paulo: Ed. Itatiaia, 1981. p.27.

\section{2}

Ibidem, p.38.

73

Ibidem, p.42. atuar em diligências no referido ano, 11 possuiam familia no período da morte de Manuel Jorge Coelho. A relevância do fato reside na constatação de que, pelo menos teoricamente, seriam estes escravos homens na referida faixa etária que poderiam ser "recrutados" para acompanhar seu senhor como braço armado. Vejamos um exemplo.

No dia 24 de junho de 1730 era celebrado na Igreja Matriz de Nossa Senhora de Nazaré, freguesia de Cachoeira do Campo, o matrimônio de Antonio e Joanna, escravos de Manuel Jorge Coelho67. Antonio e Joanna eram naturais da África, ele classificado com a etnia Benguela e ela com a etnia Congo, e a idade estimada ao se casarem seria de 35 anos para o marido e 33 para a mulher. A união desse casal cativo foi longa e estável, fato constatado pela idade e quantidade de filhos do casal. Ao serem arrolados os escravos no inventário de Manuel Jorge Coelho constava que a idade do filho mais velho de Antonio e Joanna era de 15 anos, o que denota que eles viviam juntos ilicitamente há muitos anos, união que depois acabou sendo selada com o sagrado matrimônio. Tiveram ainda um enlace profícuo em relação à prole visto que tiveram cinco filhos: Gervásio com 15 anos, Bernarda com 10 anos, Antônio com 7 anos, Faustino com 5 anos e Geraldo com 2 anos $^{68}$. Como se vê, a família de Antonio e Joanna pode ser considerada uma bem sucedida família escrava devido sua estabilidade, duração longa da união e prole numerosa.

Em 1720 Antonio estava com 25 anos e muito provavelmente acompanhou o dito potentado em suas diligências para ajudar no ataque ao quilombo do Caraça e na contenção do levante de Vila Rica69. Como constatado pela idade de seu filho mais velho, ele vivia em união marital ilícita desde pelos menos seus 23 anos com uma escrava do plantel. Este talvez pode ter sido um forte mecanismo que Manuel Jorge Coelho possuia para negociar com este cativo, e este pode ter se utilizado desta oportunidade para manter sua ainda incipiente família unida, no que, como visto, foi muito bem sucedido. Se no período de 1723, devido ao relativo desequilibrio sexual, poderíamos pensar em uma lógica de formação de famílias neste plantel comandada pelo senhor, na qual ele distribuiria suas mulheres como recompensa aos cativos, posteriormente aos escravos de Manuel Jorge Coelho foram se abrindo maiores possibilidades de constituição de famílias estáveis, mesmo no universo duro da mineração, ocorrendo inclusive uma maior difusão do casamento oficial entre a escravaria70.

Outro exemplo que reforça o que acabamos de dizer surge quando analisamos o caso do coronel Salvador Fernandes Furtado de Mendonça, natural de Taubaté que no final do século XVII saiu de sua terra natal para adentrar o interior mineiro. Em sua jornada chegou primeiramente à região de Itaverava onde descobriu ouro, "achando a novidade do novo descobrimento de ouro da Itaverava marchou para o Rio de Janeiro dando conta do novo descobrimento do ouro ao governador"71. Em 1701 Salvador Fernandes mandou seu filho Bento Fernandes Furtado explorar o ribeiro de Nossa Senhora do Bom Sucesso, no qual também descobriu ricas lavras de ouro 72 . Neste mesmo período, "chegando notícia de que se descobriram faisqueiras as margens do rio que se denominou Ribeirão do Carmo", Salvador Fernandes deixou suas lavras em Bom Sucesso e se deslocou para o local inicialmente chamado de Morro Grande, depois São Caetano, se instalando no arraial chamado "o de cima" na Vila do Carmo, onde inclusive fez a primeira capela da região ${ }^{73}$. 
TAUNAY, Afonso de. Relatos sertanistas. São Paulo: Ed. Itatiaia, 1981. p.44

75

Casa Setecentista de Mariana, $2^{\circ}$ ofício Inventário post-mortem de Salvador Fernandes Furtado de Mendonça. Códice 138, auto 2800, (1725).

\section{6}

Cf. FRAGOSO, João. À Espera das frotas: microhistória tapuia e a nobreza principal da terra (Rio de Janeiro, c.1600 - c.1750). Tese apresentada no Concurso Público para Professor Titular de Teoria da História da UFRJ. Rio de Janeiro: 2005, ver especialmente cap. 2

\section{7}

Política aqui é compreendida como os meios pelos quais o poder é utilizado para influenciar o alcance e o conteúdo das interações entre grupos sociais.

78

Cf. FRAGOSO, João. Op.Cit., p.117.

\section{9}

ENGEMANN, Carlos. Da comunidade escrava: Rio de Janeiro, séculos XVII-XIX. In: FLORENTINO, Manolo (Org.). Tráfico, cativeiro e liberdade. Rio de Janeiro, séculos XVII-XIX. Rio de Janeiro: Civilização Brasileira, 2005. p.203.
Cabe sublinhar que em tais entradas indivíduos como Salvador Fernandes e seu filho iam com seus parentes, escravos e cabedais, "gastando meses nas diligências, com soldados e escravos, com fomes, picadas de cobras e muito risco de vida"74, o que implicava em refinadas negociações e reciprocidades com tais grupos. No inventário de seus bens, aberto em 1725 na freguesia de São Caetano na Vila do Carmo, encontramos arrolado um plantel de 61 cativos. Neste, o desequilibrio sexual era alto, visto que $72,13 \%$ eram homens e apenas $27,87 \%$ eram mulheres. Não obstante, encontramos 23 cativos, ou seja, uma porcentagem de 37,70\%, unidos por relações de parentesco. Também neste plantel os arranjos familiares eram organizados de diferentes formas, sobressaindo as relações sancionadas pela igreja. Ao todo existiam seis casais unidos legalmente e com relativa estabilidade marital75. Isto sugere que as organizações parentais (sancionadas ou não) não eram estranhas ao cotidiano cativo e que a presença de tais familias neste plantel poderia fazer parte de uma estratégia de Salvador Fernandes para que este conseguisse certa legitimidade perante sua escravaria, na medida em que tais fenômenos, por fazerem parte dos anseios dos cativos, poderiam ser utilizados para validar posições sociais ${ }^{76}$.

Mais do que o aumento demográfico no plantel, os ganhos que estas familias cativas podiam trazer para os senhores se encontram na esfera da política ${ }^{77}$, pois com o uso de tais mecanismos indivíduos como Manuel Jorge Coelho e Salvador Fernandes Furtado buscavam conseguir legitimidade e mando, assim como atender a certos interesses pretendidos pelos escravos ${ }^{78}$. Em outros termos, para o senhor, tal fenômeno era uma forma de amenizar os medos e tensões do cativeiro e conseguir legitimidade perante seus cativos, para que pudesse se dispor dos mesmos na formação de "milicias privadas" para suas diligências enquanto poderosos locais. Tal fenômeno era, portanto, canal vital de reciprocidade para que conseguissem o apoio necessário (traduzido em braços armados) na sua constante movimentação para "mandar", ascender socialmente e ai se manter. Do ponto de vista do escravo, dentre outras coisas, a possibilidade de constituir uma familia era significativa e vista como um enorme ganho, pois através disso podiam conseguir uma ascensão social intracativeiro, estabelecer alianças e conexões de amizades ${ }^{79}$. Mesmo em um universo onde se relata a dureza do trabalho nas minas e o elevado nível de exploração, os escravos conseguiram ou procuraram "acomodar-se" a sua nova realidade com intuito de tornar menos penosa suas condições de vida.

\section{Conclusão}

0 quadro esboçado ao longo do texto procurou indicar que era essencial para os potentados locais estabelecer negociações e reciprocidades com os chamados "grupos subalternos", no caso os escravos, pois isso era fundamental para a viabilização da sua autoridade; seja porque o exercício de seu mando não era algo isolado da sociedade em que se inseriam e, portanto, era algo que necessitava do consentimento dos demais grupos; seja porque oferecendo seus negros e fazendas a el Rey, tais poderosos alargavam seus leques de mercês e privilégios, maximizando prerrogativas de mando e, desta forma, reafirmavam sua "qualidade" social. Por outro lado este mesmo processo propiciava um auxillio na manutenção e melhora da sobrevivência dos cativos, denotando assim que ambos os atores em foco lançavam mão 
80

Cf.: FRAGOSO, João. $\dot{A}$ Espera das frotas: microhistória tapuia e a nobreza principal da terra (Rio de Janeiro, c.1600 - c.1750). Tese apresentada no Concurso Público para Professor Titular de Teoria da História da UFRJ. Rio de Janeiro: 2005. de estratégias que Ihes propiciassem maior margem de manobra na sociedade colonial.

Dito de outro modo, para os senhores, as negociações e ligações de reciprocidade com seus escravos abriam possibilidades para o alargamento do seu cabedal político, econômico e simbólico, através da realização de ações valorosas em nome do Rei às custas de sua vida, fazendas e negros $\operatorname{armados}^{80}$. Para os escravos, tais práticas foram uma grande aliada na melhora de sua sobrevivência, na medida em que possibilitavam inúmeros ganhos, tais como a constituição de família, elemento que proporcionava o estabelecimento de alianças parentais, de amizade e uma vida comunitária. 